\title{
Strong earthquakes included «by chance» in Italian catalogues: single cases or a hint of more?
}

\author{
Viviana Castelli \\ Istituto Nazionale di Geofisica e Vulcanologia, Sezione di Milano, Sede di Ancona, Italy
}

\begin{abstract}
In principle, a few of the strong earthquakes $\left(I_{0} \geq 8 / 9, M \geq 5.8\right)$ that affected Italy in the past may still be missing from parametric catalogues or be listed there as lesser events, their actual strength unrealized. This seems a reasonable enough inference, given that some strong earthquakes were listed by catalogues quite by chance, from information drawn, mainly or even solely, from a single source. Had this source been destroyed before catalogue compilers were able to consider it, or had they for any reason overlooked it, the earthquake it recorded could also have been missed or underestimated. This paper examines the two most peculiar Italian cases of «single-source earthquakes» (1561 «Vallo di Diano?»; 1639 «Amatrice?»). Is all relevant information on each event really tied up in a single source? And if so, why? Finally, are these cases unique or do they share any common features that could, by occurring elsewhere, act as markers for situations where forgotten earthquakes could still lurk undetected?
\end{abstract}

Key words historical seismology - earthquake catalogue completeness

\section{Introduction}

It is unlikely that many strong earthquakes $\left(I_{0} \geq 8 / 9, M \geq 5.8\right)$ are still missing from Italian catalogues: the latest such catalogue (CPTI Working Group, 1999) lists 141 of them, and there are physical limits to the amount of energy that Italian seismogenic structures can have released. Unlikely, however, does not mean impossible. In principle at least, a few strong earthquakes could still be missing out-

Mailing address: Dr. Viviana Castelli, Istituto Nazionale di Geofisica e Vulcanologia, Sezione di Milano, Sede di Ancona, c/o Centro Assistenza Protezione Civile Regione Marche, Strada Statale Cameranese, 60029 Passo Varano (AN), Italy; e-mail: castelli@mi.ingv.it right or lurking in disguise in the lower échelons of catalogues, their actual strength underestimated (there could also be some overestimated impostors in the upper échelons, but this is another story).

How many, if any? A numerical answer could be worked out in many ways and lead to many results. It is reasonable to think that any results obtained would appear more or less convincing according to each user's outlook. As a roundabout, even empirical but perhaps more convincing way to the same end, it was decided to single out some extreme cases of strong earthquakes that could reasonably be said to have been catalogued only «by chance», and to look at them closely. These earthquakes only narrowly avoided being left out of catalogues. Was there some special reason for this to happen in these particular cases? And are they unique or do they share some common features, a pattern whose re-appearance in other, seemingly earthquakeless areas 
could mark the occurrence of some as yet undetected seismic event?

\section{What does «catalogued by chance» mean?}

It will be assumed in this paper that strong earthquakes can be said to have been catalogued «by chance» when:

- All, most or the major part of the available information (as collected by standard studies and seismological compilations and summed up in a catalogue record) can be traced back to one «mother-source».

- Any other source known to studies/compilations is either derivative (i.e. based on the «mother-source») or - if original - makes only a minor contribution to general knowledge (e.g., it covers one or a few sites versus many sites covered by the «mother-source»; describes minor effects only, etc.).

Such situations do occur in Italy and are quite normal, in some cases: for instance during the historical periods conventionally known

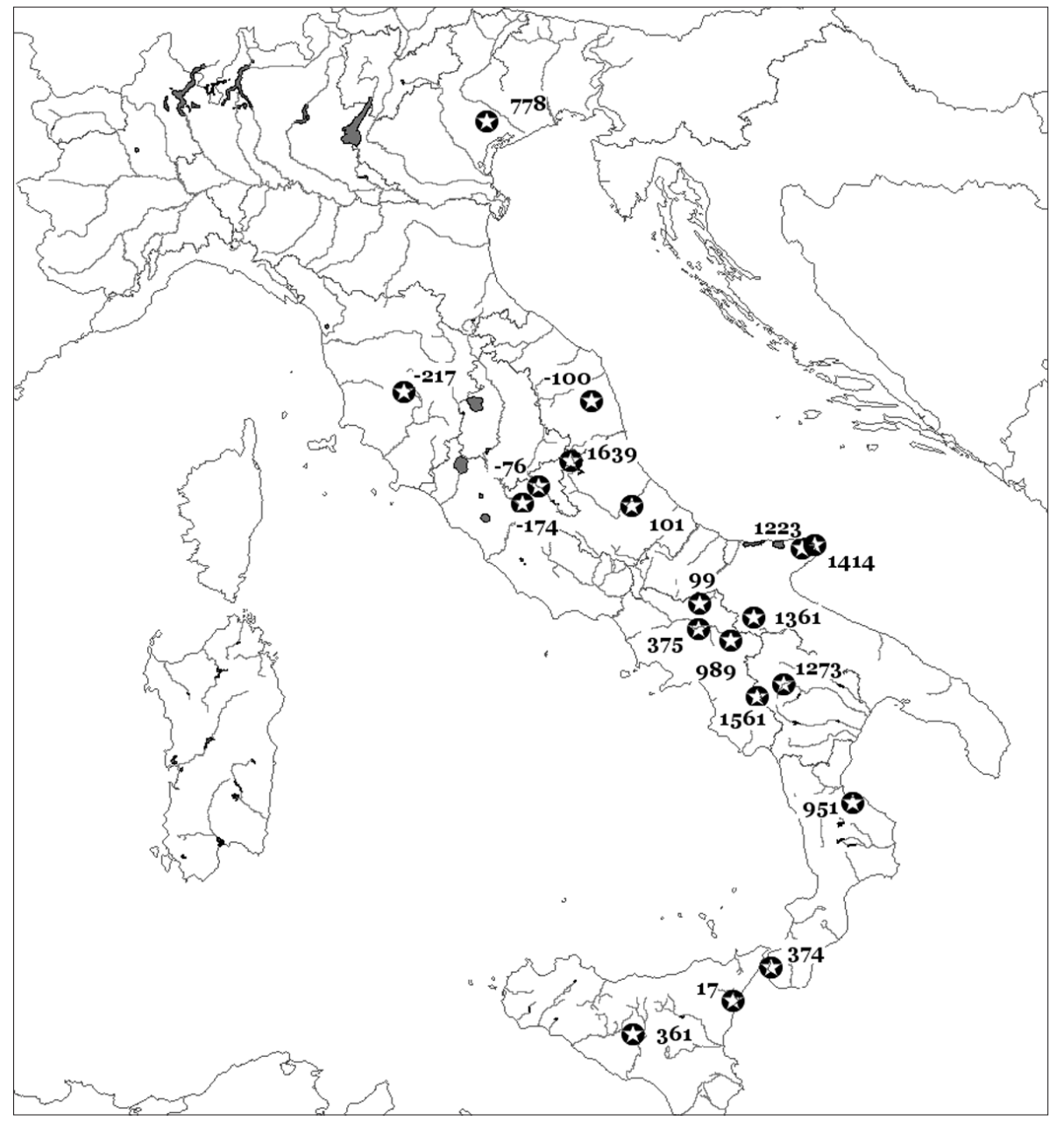

Fig. 1. «Single-source» strong earthquakes listed in CPTI Working Group (1999). 
Strong earthquakes included «by chance» in Italian catalogues: single cases or a hint of more?

Table I. CPTI Working Group (1999) «single-source» strong earthquakes.

\begin{tabular}{|c|c|c|c|c|c|c|c|c|c|c|c|}
\hline Year & Month & Day & $\mathrm{Hr}$ & Min & Area & Study & $\begin{array}{c}\mathrm{N} . \\
\text { points }\end{array}$ & $\begin{array}{c}I_{0} \\
\text { MCS }\end{array}$ & Lat. & Long. & $M$ \\
\hline 217 B.C. & 06 & - & - & - & Etruria & CFTI & 2 & 10 & 43.250 & 11.250 & 6.6 \\
\hline 174 B.C. & - & - & - & - & Sabina & CFTI & 1 & 10 & 42.250 & 12.670 & 6.6 \\
\hline 100 B.C. & - & - & - & - & Picenum & CFTI & 1 & $8-9$ & 43.170 & 13.500 & 5.8 \\
\hline 76 B.C. & - & - & - & - & Rieti & CFTI & 1 & 10 & 42.400 & 12.870 & 6.6 \\
\hline 17 & - & - & - & - & Reggio C.-Sicily & CFTI & 2 & $8-9$ & 37.800 & 15.200 & 4.7 \\
\hline 99 & - & - & - & - & Circello & CFTI & 1 & $9-10$ & 41.350 & 14.800 & 6.3 \\
\hline 101 & - & - & - & - & S.Valentino in A.C. & CFTI & 1 & $9-10$ & 42.230 & 13.980 & 6.3 \\
\hline 361 & - & - & - & - & Sicily & CFTI & 1 & 10 & 37.500 & 14.000 & 6.6 \\
\hline 374 & - & - & - & - & Reggio Calabria & CFTI & 1 & $9-10$ & 38.100 & 15.650 & 6.3 \\
\hline 375 & - & - & - & - & Benevento & CFTI & 1 & 9 & 41.130 & 14.780 & 6.0 \\
\hline 778 & - & - & - & - & Treviso & CFTI & 1 & $8-9$ & 45.670 & 12.250 & 5.8 \\
\hline 951 & - & - & - & - & Rossano & CFTI & 1 & 9 & 39.570 & 16.630 & 6.0 \\
\hline 989 & 10 & 25 & - & - & Irpinia & CFTI & 7 & 9 & 41.020 & 15.170 & 6.0 \\
\hline 1223 & - & - & - & - & Gargano & CFTI & 5 & 9 & 41.850 & 16.030 & 6.0 \\
\hline 1273 & - & - & - & - & Potenza & CFTI & 1 & $8-9$ & 40.630 & 15.800 & 5.8 \\
\hline 1361 & 07 & 17 & 19 & 30 & Ascoli Satriano & CFTI & 5 & 9 & 41.230 & 15.450 & 6.0 \\
\hline 1414 & - & - & - & - & Vieste & CFTI & 1 & $8-9$ & 41.880 & 16.180 & 5.8 \\
\hline 1561 & 08 & 19 & 14 & 10 & Vallo di Diano & CFTI & 30 & $9-10$ & 40.520 & 15.480 & 6.3 \\
\hline 1639 & 10 & 07 & 00 & 30 & Amatrice & DOM & 27 & 10 & 42.636 & 13.252 & 6.6 \\
\hline
\end{tabular}

as Antiquity and Early Middle Ages (loosely, up to 1000 A.D.). Italy, however, is a country with a massive historical record. In the socalled High Middle Ages (or similar) - roughly the 1100's-1400's - it becomes more and more peculiar that major Italian earthquakes are recorded only by one source. From the late 15 th century onwards (loosely marking the start of what European historiography calls the Modern Age) a single-sourced, strong Italian earthquake is something of a curiosity. Medieval Italy was already more literate than most other European countries, but in the Modern period the production/preservation rates of public and private written records increase enormously all over Europe, boosted by the invention of mechanical printing, the spread of literacy and the growth of bureaucracy. Of course one has to make allowances for the loss of uncountable records and for the fact that only a small fraction of those actually written can be expected to have dealt with earthquakes. However, roughly from the 16th century onwards the historical seismologist is quite justified in expecting that most strong earthquakes be the subject of several independent written testimonies. Any exception to this rule of thumb is remarkable enough in itself to be worth looking into more closely.

\section{3. «Single-source» strong earthquakes in the Italian catalogues}

The Parametric Catalogue of Italian Earthquakes (CPTI Working Group, 1999) lists 141 strong earthquakes with parameters derived from analytical studies giving references to sources. Of these, 19 can be traced back to a single source (fig. 1; table I).

Are these cases normal, in their own timecontext? Most (ten) occurred in the period conventionally known as Antiquity (table IIa), a remote time-frame in which scarcity and sparseness of information (mostly coming from literary fragments and epigraphs) are quite normal. The same applies to the three cases dated in the so-called Early Middle Ages (table IIb), given the scarcity of recording agencies, difficult communications, low literacy levels and other obstacles to good 
Table IIa-d. Time-distribution and sources of «single-source» strong earthquakes.

\begin{tabular}{|c|c|c|}
\hline Date & Area & Mother-source $(*)$ \\
\hline \multicolumn{3}{|l|}{ (a) } \\
\hline \multicolumn{3}{|c|}{ Classical Antiquity } \\
\hline 217 B.C. & Etruria & $\begin{array}{l}\text { Antipater ( } 2 \text { nd century B.C.) quoted } \\
\text { by Cicero ( } 1 \text { st century B.C.) }\end{array}$ \\
\hline 174 B.C. & Sabina & Titus Livius (1st century B.C.) \\
\hline 100 B.C. & Picenum & Julius Obsequens (4th-5th century A.D.) \\
\hline 76 B.C. & Rieti & Julius Obsequens (4th-5th century A.D.) \\
\hline 17 A.D. & Sicily-Calabria & Flegon of Tralles (2nd century A.D.) \\
\hline 99 A.D. & near Circello (BN) & Memorial Tablet (CIL 9/1466) \\
\hline 101 A.D. & near S. Valentino in Abruzzo Citeriore (PE) & Memorial Tablet (CIL 9/3046) \\
\hline 361 A.D. & Sicily & Libanius of Antiochia (4th century A.D.) \\
\hline 374 A.D. & Reggio Calabria & Memorial Tablet (Année Ep. 1913/227) \\
\hline 375 A.D. & Benevento & Symmachus (4th century A.D.) \\
\hline \multicolumn{3}{|l|}{ (b) } \\
\hline \multicolumn{3}{|c|}{ Early Middle Ages } \\
\hline 778 A.D. & Treviso & $\begin{array}{l}\text { Annales Laureshamenses (9th-10th century } \\
\text { A.D.), written in Lorsch (Mainz, Germany) }\end{array}$ \\
\hline 951 A.D. & Rossano & $\begin{array}{l}\text { Bartolomeo da Rossano (10th-11th century } \\
\text { A.D.) }\end{array}$ \\
\hline 989 October 25 & Irpinia & Leo Cardinal of Ostia (11th-12th century \\
\hline A.D. (or 990) & & A.D.), written in Montecassino Abbey \\
\hline \multicolumn{3}{|l|}{ (c) } \\
\hline \multicolumn{3}{|c|}{ High Middle Ages } \\
\hline 1223 & Gargano & Sarnelli (1680) \\
\hline 1273 & Potenza & $\begin{array}{l}\text { Lost document from the Neapolitan } \\
\text { Chancery, } 1273 \text { (Filangieri, 1958) }\end{array}$ \\
\hline 1361 July 17 & Ascoli Satriano & Villani (14th century) \\
\hline 1414 & Vieste & $\begin{array}{l}\text { Lost document from the Neapolitan } \\
\text { Chancery, undated (Giuliani, 1768) }\end{array}$ \\
\hline \multicolumn{3}{|l|}{ (d) } \\
\hline \multicolumn{3}{|c|}{ Early Modern period } \\
\hline 1561 & Vallo di Diano & Pacca (16th century) \\
\hline 1639 & Amatriciano & Tiberii $(1639 a, b)$ \\
\hline
\end{tabular}

(*) For complete references see Guidoboni (1989).

record-keeping that affect this historical period.

A sadder but not really odder case is that of the four earthquakes which occurred in the socalled High Middle Ages (table IIc). Generally speaking, a comparatively large amount of records should be available for this period of Italian history, with a most noticeable exception in peninsular Southern Italy, then the Kingdom of Naples. The most authoritative and comprehensive medieval source of information for this area (the Royal Neapolitan Chancery records) was destroyed in 1943, before any systematic investigation of its potential earthquake record was made. It is now impossible to tell exactly how many earthquakes the Neapolitan Chancery papers originally recorded, apart from those few that were dealt with in such documents as were 
occasionally transcribed, summarized or otherwise quoted in historical and/or seismological compilations produced before 1943. All table IIc earthquakes being located in Southern Italy, it is to be expected that they are poorly documented.

The earthquakes of 1561 and 1639 (table IId) are another story. They occurred in the socalled Early Modern Age (1500's-1700's), a time-frame overflowing with potential recorders. Professional printers and reporters thrived, cheap earthquake pamphlets were sold at market-stalls, red-tape letters were produced in triplicate. In such a garrulous age, why should two strong earthquakes attract such scant attention that only one truly relevant record of each was made? Were they in fact less strong than we think they were? Did most of the original records get lost? Or was it all the fault of past earthquake compilers - whose work still forms the backbone of modern earthquake catalogues - for contenting themselves with retrieving only part of the potentially available records? Or what else?

\section{The earthquakes of 1561 (Vallo di Diano?) and 1639 (Amatrice?)}

In present-day knowledge, both table IId events are some place's «only destructive earthquake to date». In the 1561 case, the place is Vallo di Diano, a valley some $100 \mathrm{~km}$ southeast of Naples, on the western side of the Apennines. In the 1639 case, the place is the Amatrice Basin, on Latium's northernmost tip. When the earthquakes occurred, both areas belonged to the Kingdom of Naples, that was in its turn an appendage of the Kingdom of Spain. Both were provincial backwaters, under feudal rule, and rather far from main thoroughfares and larger towns.

Both earthquakes were studied, independently and at roughly the same time, by two research teams working for the compilation of the parametric catalogues CFTI (Boschi et al., 1995, 1997, 2000) and NT4.1 (Camassi and Stucchi, 1997). The latest CPTI99 catalogue has adopted CFTI parameters for the 1561 earthquake and NT4.1 parameters for the 1639 earthquake. The alternative parameters produced by the available studies differ to varying extents. Exploring these differences is not this paper's aim. Suffice to say that, whatever their reasons, they do not derive from using different sets of historical sources. In fact, the concurrent studies on both earthquakes rely on the same core of information, derived from single sources.

A data set which is derived from a single source cannot avoid some taint, not so much of bias as of borrowing from a great historian, «the unavoidable fallacy of the point of view» (Bloch, 1997). The accepted 1561 earthquake location was recently challenged by Mucciarelli et al. (2000), on the grounds that the available data set could be biased by possible vagaries in the distribution of urban settlements at the time and/or by damage-enhancing site effects. As quite similar objections could doubtlessly be made in the 1639 case, both epicentral locations should be taken with a pinch of salt pending further consideration. Hence the question marks.

\subsection{Basic knowledge to date on the 1561, Vallo di Diano (?) earthquake}

In 1561, a sizable chunk of the Kingdom of Naples was affected by two major seismic events within a month, with some lesser shocks in between. According to the «mother-source» (Pacca 16th century, on which more anon), the first one, on 31 July 1561, affected the provinces of Terra di Lavoro, Principato and Basilicata (lying between the Apennines and the Tyrrhenian coast, Naples and the Calabrian borders). Though Pacca says it «weakened all buildings in those provinces ... so that they collapsed under the onslaught of the latter one», the only places he names are Buccino, a small town some $100 \mathrm{~km}$ south-east of Naples as the crow flies, which suffered heavy damage, and Naples where the shock was felt.

Two other sources (unrelated to Pacca, as far as one can tell) add that, on the same day and at roughly the same time, an earthquake fissured most buildings in Avellino (Bellabona, 1656) and caused panic in Benevento (Vipera, 1635). Bellabona (1656) adds that lesser shocks were felt in 


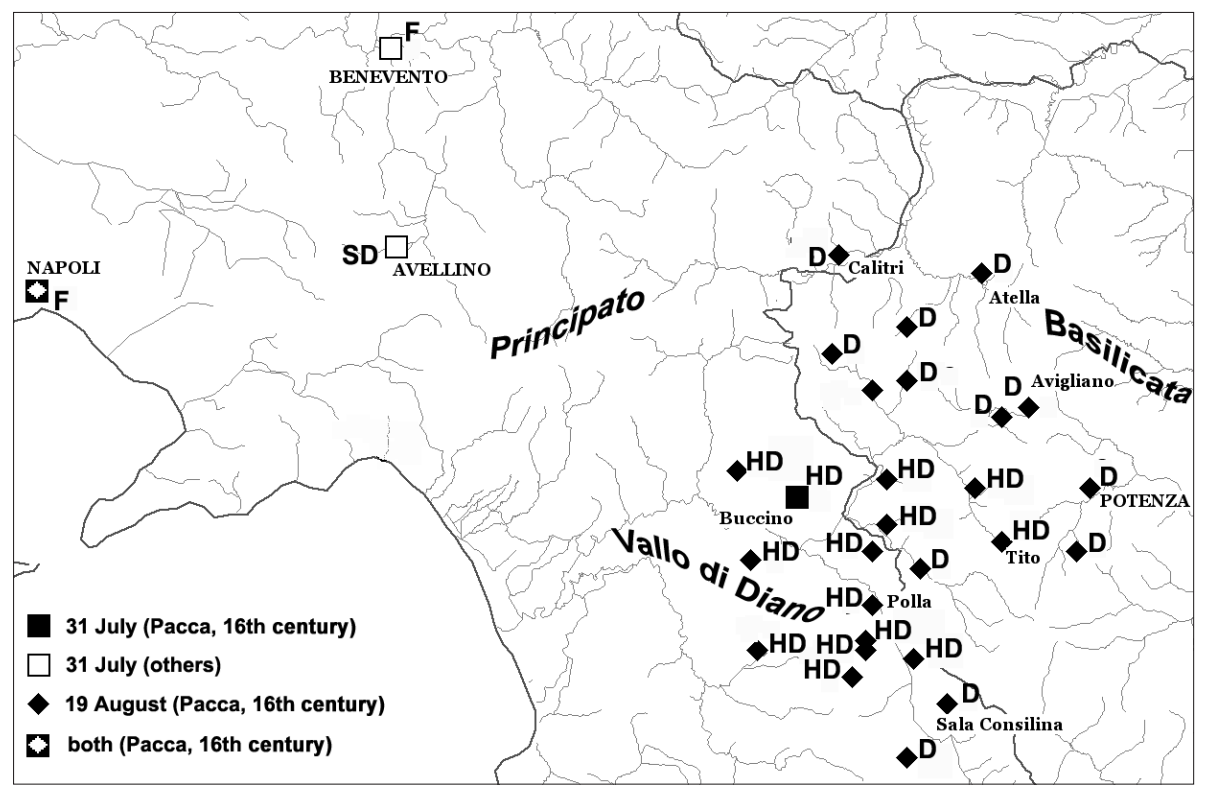

Fig. 2. The 1561 earthquake according to Pacca (16th century): HD - heavy damage; D - damage; SD - slight damage; F - felt.

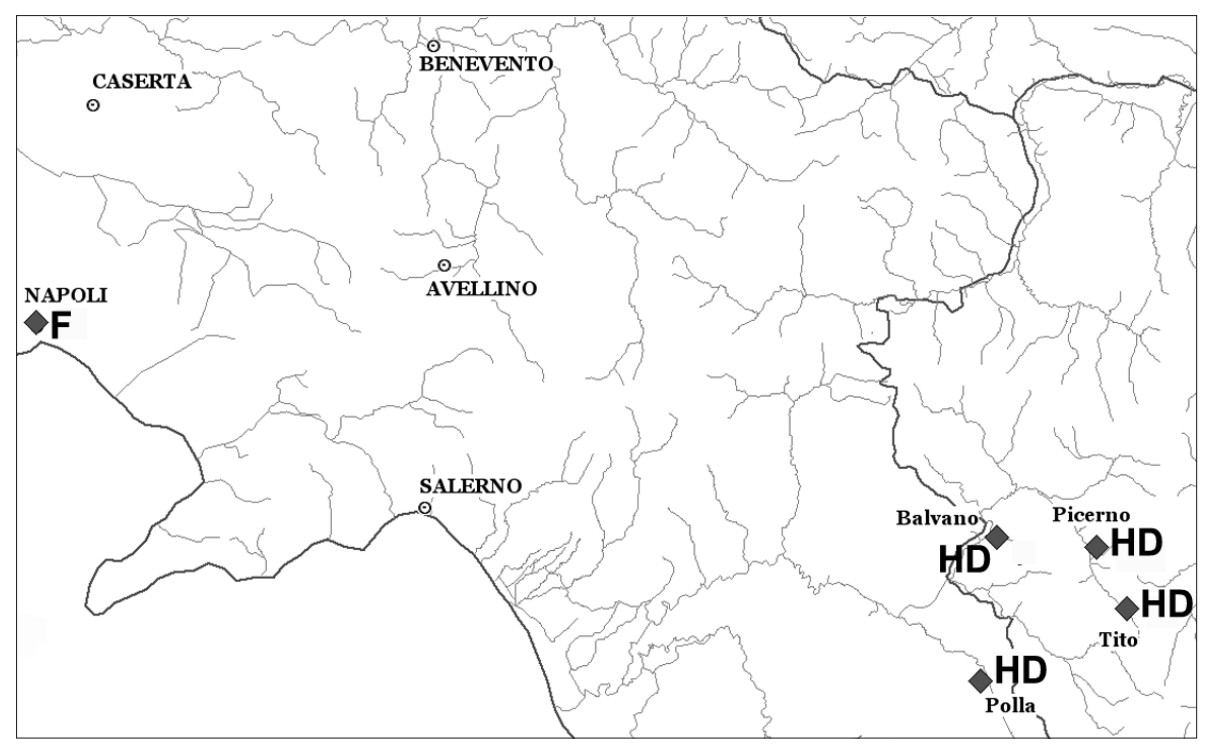

Fig. 3. Another version of the 31 July 1561 event (Pacca, 1563). HD - heavy damage; F - felt. 
Avellino for some days after. Benevento and Avellino lie roughly midway between Naples and Buccino. Evidence on them tallies with Pacca's tale as concerns date, time and subsidiary circumstances (a violent storm preceeding the earthquake by a couple of hours), so increasing the credibility of the whole picture.

The second major event described in the «mother-source» occurred on 19 August 1561 and affected, we are told, Principato and Basilicata. Here Pacca (16th century) lists 29 severely damaged towns and villages, several of them close to Buccino. Buccino itself, however, is not mentioned (fig. 2). Of course it seems unlikely that Buccino was singled out for damage on 31 July and escaped untouched on 19 August (and vice versa). In fact, a later chapter of Pacca (16th century) states that «in 1561 the earthquake hit Buccino twice within a month».

As it will be explained later, the Pacca (16th century) description of the 1561 earthquake was never published. A shortened, rather garbled version, was however included in a printed work by the same author (Pacca, 1563). It gives quite a different picture of the 31 July event (fig. 3) and, for the 19 August event, only a generic mention of «more damage in the Vallo di Diano». This version would be mirrored in a trickle of secondhand mentions of the 1561 earthquake to be found in 16th and 17th century historical compilations.

\subsection{Basic knowledge to date on the 1639, Amatrice (?) earthquake}

The «mother-source» (Tiberii, 1639a,b) describes three events which occurred on 7, 14 (or 8 and 15 , according to what one makes of the original time-quotes) and 17 October 1639 (table III). Each of the earlier two ones purportedly caused heavy damage in a different set of sites inside the Amatrice Estate. This included the namesake town and 67 villages, and was a fief of prince Alessandro Orsini (Massimi, 1958). Tiberii (1639a) also reports damage in four sites not belonging to the Amatrice Estate (Accumoli, Montereale, Poggio Cancelli and Roccasalli), without specifying which event was responsible for it. However, all the sites in-

Table III. 1639 earthquake effects according to Tiberii (1639a,b).

\begin{tabular}{|c|c|c|c|c|}
\hline & $7 / 8$ October & 14/15 October & «At the same time» $(?)$ & 17 October \\
\hline $\begin{array}{c}\text { Tiberii } \\
\text { (1639a) }\end{array}$ & $\begin{array}{c}\text { Amatrice } \\
\text { Campo Tosto } \\
\text { San Martino } \\
\text { Collalto } \\
\text { Pinaca } \\
\text { Filetta } \\
\text { Nescaia } \\
\text { S. Lorenzo Abbey }(*) \\
\text { Padarga } \\
\text { Cantone } \\
\text { Corva (\#) } \\
\text { Forcella } \\
\text { Capricchio } \\
\text { La Leia }\end{array}$ & $\begin{array}{c}\text { Amatrice } \\
\text { Saletta } \\
\text { Corsenito } \\
\text { Casale } \\
\text { Rocca (\#) } \\
\text { Torreto } \\
\text { Colle Basso (\#) } \\
\text { Pasciano } \\
\text { Santo Iorio } \\
\text { Colle Moresco }\end{array}$ & $\begin{array}{c}\text { Accumulo (+) } \\
\text { Rocca de Salli }(+) \\
\text { Poggio Cancello (+) } \\
\text { Monte Reale (+) }\end{array}$ & \\
\hline $\begin{array}{c}\text { Tiberii } \\
(1639 b)\end{array}$ & All the above & All the above & $\begin{array}{c}\text { All the above } \\
\text { Recanati } \\
\text { Rieti }\end{array}$ & Amatrice \\
\hline
\end{tabular}

(+), localities outside the Amatrice Estate; (\#), unidentified localities; $(*)$, possibly not a locality (as Tiberii believed) but a church in Amatrice (Lupachino, 1669). 


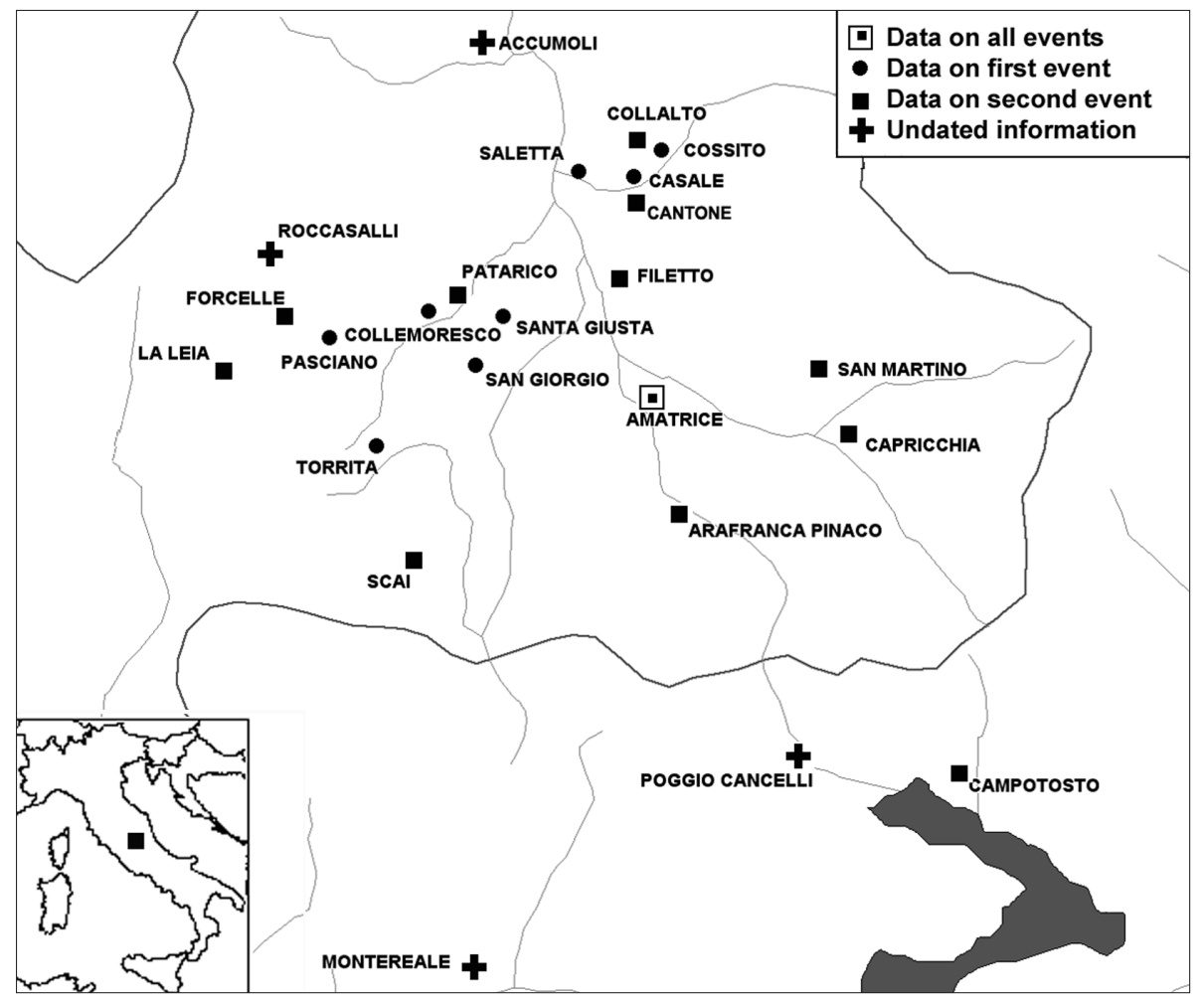

Fig. 4. The 1639 earthquake according to Tiberii (1639a,b).

volved are so close (fig. 4) that it seems unlikely that some were damaged by the first event while others, their close neighbours, remained untouched until a week later.

Tiberii (1639b) piles on colourful details of popular reactions and curious natural phenomena connected to the earthquake, describes one more event that caused further damage in Amatrice on 17 October and winds up his tale adding that «at the aforesaid time» the earthquake «was felt in Recanati [near the mid-Adriatic coast] and caused fear in Rieti». This piece of news is generally interpreted as proof that the main Amatrice event was felt as far as the Marche coast, though of course it could also conceivably be related to some other, otherwise still unknown, local earthquake.

\section{The «mother-sources»}

\subsection{The 1561 key witness: Colanello Pacca}

According to present-day knowledge, the key-witness of the 1561 earthquake is one Colanello (or Niccolò Agnello) Pacca, a Neapolitan university professor with interests ranging from philosophy to history and genealogy (table IV). The Discorso del Terremoto (Pacca, 16th century), probably compiled between 1561 and 1580, was his most elusive work. As far as it has been possible to ascertain, the only known contemporary reference to this book is a self-quote: after briefly mentioning the 1561 earthquake in his Storia del Regno di Napoli (Pacca, 1563), 
Pacca refers any reader wishing for more details to «my treatise on earthquakes». When Pacca died, in 1587, the Discorso was still unfinished. It remained unpublished and forgotten for centuries. At least, none of several 17 th to mid-19th century. Neapolitan literary and seismological compilations listing Pacca's works seems aware of its existence. It was first brought into comparative limelight in 1891 by Giuseppe Mercalli, who published a selection of 22 descriptions related to 16th century Southern Italian earthquakes (Mercal-

Table IV. Who's who? Colanello Pacca.

\begin{tabular}{ll}
\hline \hline 1534 & Born in Naples. \\
1557 & Graduates in Humanities and Medicine from Naples University. \\
& Publishes a Latin philosophy primer. \\
& Takes on the chair of Logic at Naples University. \\
& Works on 7th book of Storia del Regno di Napoli \\
& a multiple-authors work. \\
$1557 / 1562$ & Publishes another Latin philosophy primer. \\
& Starts writing Discorso del Terremoto. \\
1561 & Publishes 7th book of Storia del Regno di Napoli. \\
1574 & Takes on the chair of Aristotelian Logic at Naples University. \\
1580 & Works still on Discorso del Terremoto. \\
1582 & Takes on the chair of Metaphysics at Naples University. \\
1587 & Dies in Naples. \\
& Other known fields of interest: poetry, genealogy. \\
\hline
\end{tabular}

References: Toppi (1678), Tafuri (1752), Soria (1781), Minieri Riccio (1844) and Nicolini (1966).

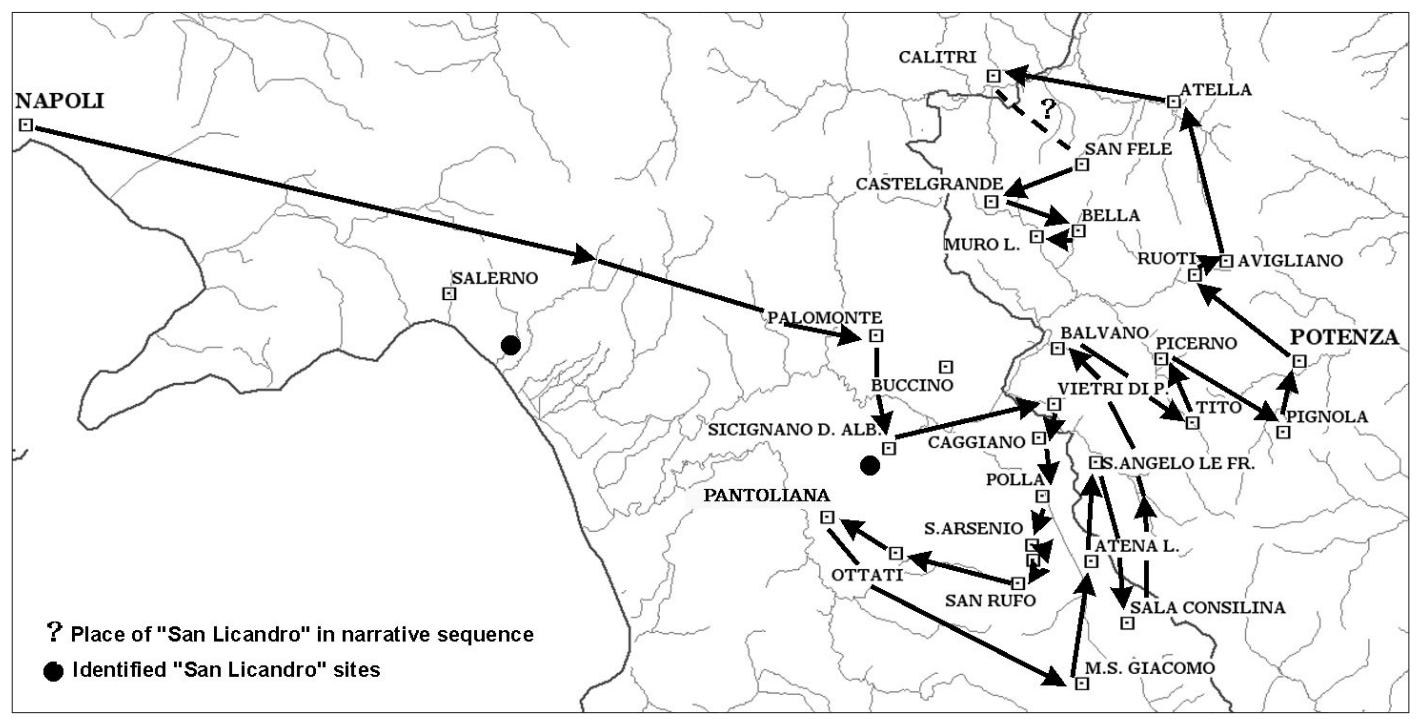

Fig. 5. The shadow of a real itinerary? Narrative sequence of the sites affected by the 19 August 1561 event in Pacca (16th century). 
li, 1891), out of a list of 350 earthquakes occurring «in all the world from its creation», which takes up about half the Discorso (Morelli, 1993). Mercalli's selection was further trimmed down - for no evident reason by Baratta (1901), who adopted only nine of the items mentioned by Mercalli (1891).

The 1561 earthquake has a special place in the Discorso because, as the author recounts, «[it] gave me the idea of undertaking such a lengthy work [and] I resolved to get as many details as possible on it». In 1561 Pacca was preparing a two-volume update of a standard multi-authored Storia del Regno di Napoli (Pacca, 1563). It was surely in his capacity of historian that he started collecting information on the earthquake. He claims his source was «a true report by trustworthy men». It is unclear who these people were: occasional travellers, envoys from the affected areas, or even government officers sent on a damage-assessing tour. The numbers Pacca gives for casualties and affected buildings per locality are finite and believable-sounding («six» or «eight» or «twenty», not «hundreds» or «innumerable»). Also interesting is that the narrative sequence in which the names of sites affected by the 29 August event are given seems to follow a real itinerary (fig. 5). The only exception is «San Licandro», listed between Calitri and San Fele, in an area where no place of this name is to be found (fig. 5 lists some alternatives). All this leads us to believe that the tale was based on reliable sources: the likeliest would be an official report of some sort, subsequently lost or still hidden in the labyrinthine Neapolitan archives or (Naples was then a subject of the Most Catholic King) perhaps even in the Spanish central archives of Simancas.

\subsection{The 1639 key witness: Carlo Tiberii}

Carlo Tiberii, proudly self-styled «a Roman citizen», wrote two journalistic pamphlets on the 1639 earthquake (Tiberii, 1639a,b). By sheer serendipity, a little information was gained on this person (table V). Apparently the black-sheep of a well-to-do bourgeois family (ACAP, 16381639), Tiberii made a living by writing comic plays and acting in them (Bragaglia, 1958; Mari- ti, 1978; Franchi, 1988). At those times it was a precarious and demeaning job: Tiberii aspired in fact to «something better» as he says in a self-vindicatory introduction to his last known play (Tiberii, 1641). Prince Marcantonio Borghese, to whom he dedicated the play, could be the influential patron that Tiberii hoped would foster his social aspirations. Whether these were fulfilled remains unknown: Tiberii disappears from history after 1643 , the printing date of his last work, a volume of poems.

As Tiberii does not figure in a census of 17 th century. Roman professional reporters (Bulgarelli and Bulgarelli, 1988), it is likely that the 1639 earthquake pamphlets were his only journalistic venture. It is unclear whether he wrote them using privileged information gleaned from contacts in the Orsini or Borghese households - Marcantonio Borghese was related by marriage to the Orsini Lord of Amatrice (Ugurgieri Azzolini, 1649) - or whether he was simply hired by a Roman printer-bookseller to spin a marketable story out of data collected some way or other.

That the pamphlets were written from a Roman point of view is shown by Tiberii's anticipation of the arrival of «better news» (Tiberii, 1639a) and his mention of the tales told by newly arrived Amatrice refugees (Tiberii, 1639b). That he was no eyewitness is also shown by his poor grasp of local geography: for instance he mistakes «San Lorenzo abbey» (the courtesy title of a church inside Amatrice; Lupachino, 1669) for a real abbey in the country. His lists of damaged sites show no trace of a conjectural real itinerary (fig. 6), contrary to Pacca's description of the 1561 earthquake. His lavish estimates of damage, escalating from «400000 scudi» (Tiberii, 1639a) to «one million gold» (Tiberii, 1639b) are clearly made up for sensation's sake, as the whole Amatrice estate had been evaluated as worth 80.000 scudi as early as 1610 (Ragioni ..., 1693).

Commercially, the pamphlets must have been a real success. Copies of the first (Tiberii, 1639a), printed in Rome around mid-October, are preserved in public libraries of Northern Tuscany, the Marches, Abruzzo, Naples and Venice, implying a largish issue and a wide circulation. It was reprinted too, in Perugia (Minieri Riccio, 1861) and Florence (British 
Table V. Who's who? Carlo Tiberii.

\begin{tabular}{|c|c|c|}
\hline ??? & & Born (Rome?). \\
\hline$? ? ?$ & & Possibly a Jesuit pupil at the Collegio Romano. \\
\hline$? ? ?$ & & In his teens, writes play Hoggi corre quest'usanza (This is the fashion now). \\
\hline ??? & & $\begin{array}{l}\text { Becomes a member of the «Academy of the Hidden Ones», a minor Roman literary } \\
\text { club. }\end{array}$ \\
\hline 1637 & & $\begin{array}{l}\text { Play Li tre amanti burlati (The three hoodwinked lovers), dedicated to Landgrave } \\
\text { Frederick of Hesse. }\end{array}$ \\
\hline 1638 & & $\begin{array}{l}\text { Last will and testament of Tiberii's mother. Small legacy to him, his brother is made } \\
\text { universal heir. }\end{array}$ \\
\hline 1639 & & Play Escharistumerotos overo i contrasti d'amore (E. or love's labours). \\
\hline & March & $\begin{array}{l}\text { Formally declares he lives apart from his father, and renounces to his inheritance for } \\
\text { a lump sum of } 100 \text { scudi. }\end{array}$ \\
\hline & Oct/Nov & $\begin{array}{l}\text { Nuova, e vera relatione del terribile, e spaventoso terremoto }[. . .] \text { (two printings in } \\
\text { Rome; one each in Perugia, Florence and Milan). }\end{array}$ \\
\hline 1640 & & $\begin{array}{l}\text { Writes new introduction to play Hoggi corre quest'usanza, now about to be printed } \\
\text { for the first time. Biographical details. }\end{array}$ \\
\hline 1641 & & $\begin{array}{l}\text { Play Hoggi corre quest'usanza printed, dedicated to Marcantonio Borghese prince of } \\
\text { Sulmona. }\end{array}$ \\
\hline 1643 & & $\begin{array}{l}\text { La fama messaggiera. Poetiche compositioni (Fame the messenger. Poems) printed } \\
\text { in Spoleto (Umbria). }\end{array}$ \\
\hline ??? & & Dies. \\
\hline
\end{tabular}

References: ACAP (1638-1639), Tiberii (1639a,b; 1641), Mariti (1978) and Franchi (1988).

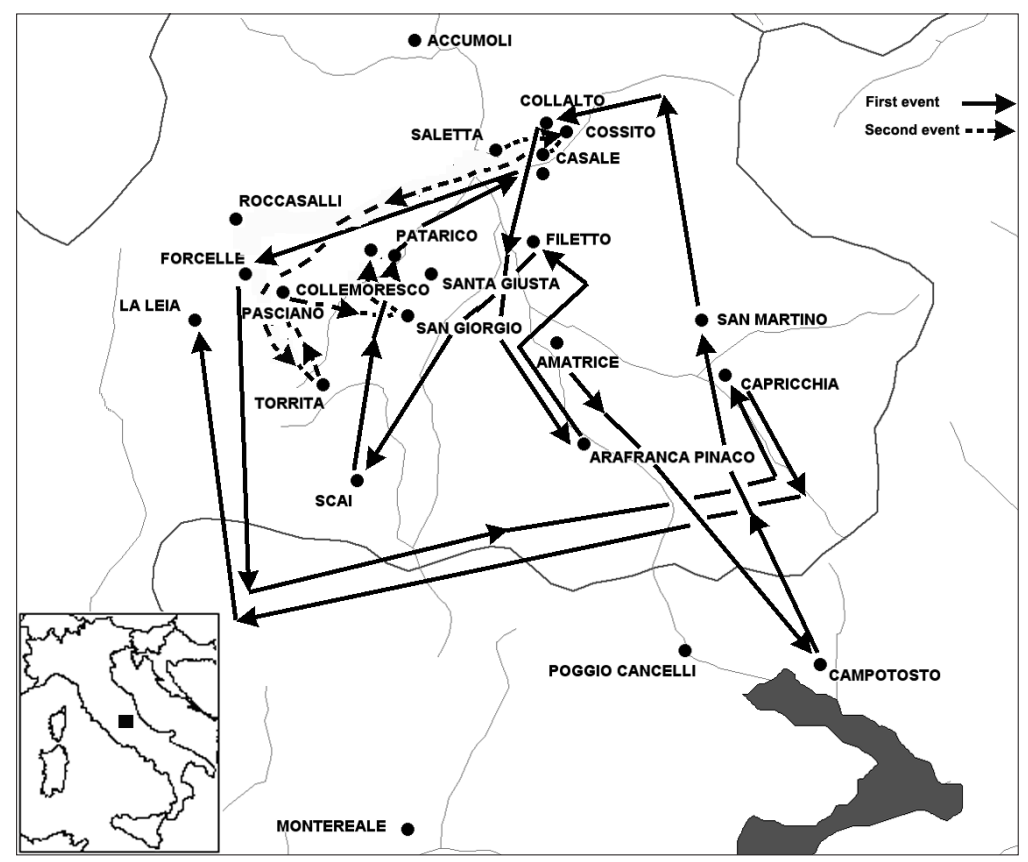

Fig. 6. No shadow of a real itinerary. Narrative sequence of the sites affected by the first two 1639 events in Tiberii $(1639 a, b)$. 
Library, 1988). The original Roman issue of the second pamphlet (Tiberii, 1639b) was printed at the end of October, probably in fewer copies. The only two known extant copies (one now missing, formerly in the Roman archive of the Company of Jesus; another in the Historical Neapolitan Society Library) come not from the Roman first printing but from a Milanese reprint, issued around 6 November. The same text was also inserted in the Milanese Avvisi, a handwritten weekly newssheet.

\section{Are they really «single-source» earthquakes or not?}

\subsection{The 1561 earthquake: old sources, new data, perchance a new map?}

The earthquakes of 1561 and 1639 are «single-source» ones, in this paper's wording and as far as the seismological tradition is concerned, because all or most of what's known of them in seismological literature (and therefrom their catalogue parameters) can be traced to a single source. This does not strictly mean that seismological studies and compilations do not know of any other sources dealing with them, but rather that - except for the descriptions set down by Pacca and Tiberi - any other source listed by seismological studies and compilations in connection with the 1561 and 1639 earthquakes is either derivative, or else it adds only minor details to the whole amount of knowledge available.

With this qualification in mind, in the case of the 1561 earthquake, apart from the 1561 «mother-source», i.e. the long handwritten description by Pacca (16th century), the seismological tradition lists:

- The abridged version by Pacca (1563), reprinted in Pacca (1591); it names only a few of the sites linked by Pacca (16th century) to the 19 August event, but connects them instead with the 31 July event.

- A few second-hand 16th and 17th century texts based on Pacca $(1563,1591)$.

- A handful of original sources, independent of Pacca, each recording the effects of the 1561 earthquake in one locality not mentioned by Pacca (Maffei, 1564; Seripando, 16th centu- ry; Vipera, 1635; Bellabona, 1656). Just to stress how much a «forever in progress» thing historical earthquake research is, though Maffei (1564) was first quoted in the Mercalli (1891) compilation, its being an eyewitness account of the earthquake as felt in Solofra was only realized while working on this paper.

If one leaves the well-trodden path of seismological tradition to look for untapped sources, the findings are rather meagre. Local municipal archives mostly lack contemporary records. In the local, sparse, mostly recent, often unreliable historiography, the remembrance of the 1561 earthquake in the Vallo di Diano and nearby areas is almost effaced by memoirs of the 1694 and 1857 earthquakes $\left(I_{0}=\mathrm{X}-\mathrm{IX}\right)$ and the 1656 plague, responsible for a drastic population drop. Positive findings include a couple of original records (table VI) and a scattering of sourceless i.e. uncheckable, therefore unreliable - recent mentions of damage purportedly wrought by the 1561 earthquake in sites not named by the older sources (Sansone and Sansone, 1959; Ricchetti, 1983; Mattia, 1986).

Interestingly enough, some of this new evidence singles out the 31 July event as more significant than Pacca made out. In Tito - a site that, according to Pacca (16th century) was damaged by the 19 August event - a 16th century memorial tablet dates the locally damaging event to 31 July «1560» (the latter hopefully being, in the light of all additional evidence, a carver's mistake). Sourceless recent evidence also refers to the 31 July event rather than to the 19 August one (fig. 7).

\subsection{The 1639 earthquake: new (but hardly mappable) data}

To all intents and purposes, Tiberi (1639a,b) remains the relevant source for anyone attempting a reconstructions of the 1639 earthquake. The only additional sources known to seismological tradition are some, yet to be identified, 17th century Annali ecclesiastici by one Scoglio, quoted by the Bonito (1691) compilation as relating that «Amatrice and villages were savaged by an earthquake in 1639». Among the references of the 1639 studies in Boschi et al. 
Table VI. 1561 earthquake memorial tablets.

\begin{tabular}{|c|c|}
\hline $\begin{array}{l}\text { Location: Tito (PZ), church of the «Congrega» } \\
\text { (destroyed by the } 1980 \text { Irpinia earthquake) }\end{array}$ & $\begin{array}{l}\text { Location: Polla (SA), facade of the castle, } \\
\text { left of main gate. }\end{array}$ \\
\hline $\begin{array}{l}\text { «Domus hec noviter constructa fuit per Venera- } \\
\text { bilem Dom[inum] Primum de Suma, Patronum, ad } \\
\text { honor[em] S[anc]ti Antonii de Padua an[n]o Divi } \\
\text { 1568. Que tota corruit a terremotu ultimo die Iulii } \\
\text { A[nno] D[omini] 1560.» }\left(^{(}\right)\end{array}$ & $\begin{array}{l}\text { «ohannes Villanus, oppido motu terrae concusso, } \\
\text { fere prostrato, viis, plateis coenobis restituto } \\
\text { adaucto, secum marchionatus titulo decorato, cas- } \\
\text { tro elegantius erecto, Pollae posuit a[nno] D[omi- } \\
\text { ni] MDXC.» }\left({ }^{2}\right)\end{array}$ \\
\hline $\begin{array}{l}\text { This house, utterly collapsed in the earthquake of } \\
\text { the last (day) of July } 1560 \text { [sic], was built anew by } \\
\text { the Reverend Lord and Patron Primo de Suma, to } \\
\text { honour the blessed St Anthony of Padua, in the } \\
\text { Lord's year } 1568 \text {. }\end{array}$ & $\begin{array}{l}\text { Giovanni Villano, having rebuild and enlarged the } \\
\text { town after the earthquake hit and almost destroyed } \\
\text { it and its streets, squares and monasteries, having } \\
\text { obtained the title of Marquis and rebuilt this castle } \\
\text { in a more elegant style put up this memorial in Pol- } \\
\text { la, in the year of our Lord } 1590 \text {. }\end{array}$ \\
\hline
\end{tabular}

(1) Communication by Don Nicola Laurenzana to the author (2001); $\left(^{2}\right)$ Bracco (1976).

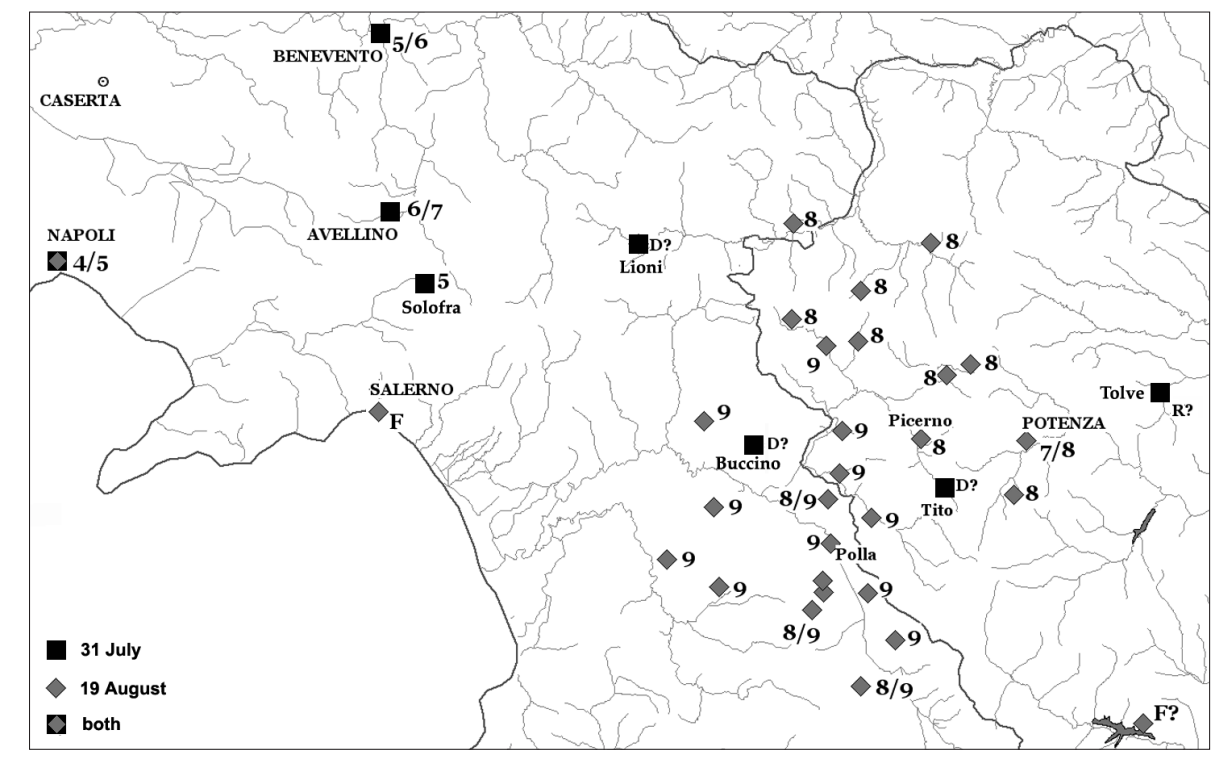

Fig. 7. The 1561 earthquake at the end of this study (I MCS). D - damage; F - felt; R - rockfall; ? - doubtful data).

$(1995,1997,2000)$ there are the almost identically-titled Annali ecclesiastici della Liguria (Schiaffino, 17th century).

A search for original 1639 records unearthed new evidence of damage in Amatrice, not in the local municipal archive (lacking any records before 1750) or in the missing Orsini feudal papers, but in those of the Bishopric of Ascoli, to which Amatrice was subjected, and in local mementoes (ACVAP, 1652; Memorial Tablet, 17th 
century; Lupachino, 1669). More interesting, however, is the evidence from the nearby region of Abruzzo, an area not previously known to have been affected by this earthquake. A contemporary diary (Ciurci, 17th century) and a reliable 18th century historical compilation (Antinori,18th century) state that the 1639 earthquake was strongly felt in the Abruzzo provincial capital, Aquila. In the Aquila district «in a range of forty miles ... many of the highest buildings were thrown down» (Antinori, 18th century). Information on minor effects in Ascoli Piceno (Marcucci, 1766) and Leonessa (Rossi da Voltaggio, 1695) also came to light.

The data about earthquake damage in the Aquila district cannot be mapped unless more details come to light (this is, unfortunately, somewhat unlikely). However, the newly discovered evidence hints, clearly enough, that the present reconstruction of the October 1639 earthquake (see, for instance: Monachesi and Stucchi, 1997) could in fact account for no more than half of the actual near field.

\section{Some final considerations}

The 1561 and 1639 earthquakes are two strong enough events that attracted less contemporary attention than one would expect (though they weren't by any means, «single-source» ones, apart from the specific sense meant here).

Why it was so, is not clear. In 1561, there were political and military matters to draw away the attention of potential witnesses. After an unlucky 1560 Spanish expedition against Djerba, Western Europe was tensely waiting for a summer large-scale attack by the Ottoman fleet. The Neapolitan Kingdom was in a frenzy of military preparations, complicated by outbursts of plague and the rebellion of the Valdensian communities of Calabria. In July, the Turkish pirate Dragut destroyed the Sicilian fleet and proceeded to pillage the Adriatic coast (Braudel, 1982). The most perfunctory browsing of contemporary newssheets shows that the whereabouts of the Turkish ships was the main interest of all correspondents (see, for instance: ASFI, 1542-1662). In 1639, on the contrary, there seems to be no such Europeansize distraction.
There could be more long-term reasons too. The examined cases occurred in quite similar circumstances, geographically and administratively. Vallo di Diano in 1561 and the Amatriciano in 1639 were secluded rural areas, far from the main thoroughfares and cultural centres: this would make it harder for inside occurrences to become known abroad in a consistent way. In such situations, even strong earthquakes could pass unobserved, whereas even quite minor shocks would have many chances of being recorded, if felt in a large town such as Naples, Venice, Rome or Florence. Another thing that could matter is that both areas were ruled by feudal families, i.e. mostly insulated from direct interference by the central government. Where the State is less likely to interfere, state records are less likely to be produced, and as a rule, these are less liable to dispersion than private family records.

Of course things could have gone differently. There are quite a few cases of 17 th century earthquakes located in various parts of the Kingdom of Naples (1638 in Calabria, 1654 in Sorano-Marsica, 1688 in Sannio and 1694 in Irpinia-Basilicata), that originated a large production of records, from pleas for economic help to damage surveys. In all these cases, large-scale searches of archival records were launched, something that did not happen in the 1561 and 1639 cases. Whether this was because these particular earthquakes were never felt as important enough to warrant the time and expense required by such an investigation, or because it was always deemed that the «mother sources» gave information enough, it is a matter of speculation.

In any case, had Pacca (16th century) and Tiberii $(1639 a, b)$ i) never been written, ii) been destroyed or iv) remained unknown to historical earthquake compilations (the background and backbone of modern parametric earthquake catalogues), the assessment of the 1561 and 1639 earthquakes would have been quite different. In fact, none of the 1561 and 1639 «additional» sources identified so far matches the «mothersources» for quantity and quality of data. In any case, it cannot be taken for granted that any of these additional sources would have come under the compilers' scrutiny, had not the compilers' 
interest first been stirred by the «mothersources». The 1561 earthquake as shown in fig. 2 (from Pacca, 16th century) is rather different from that of fig. 3 (based on Pacca, 1563). A Tiberii-less 1639 earthquake would probably be located in Aquila, rather than in the Amatriciano.

In conclusion, it can be assumed that the 1561 and 1639 earthquakes could well have been completely eclipsed owing to a multiple set of circumstances: occurring in marginal areas, being dealt with by one very detailed source, never having become «strategic» enough to warrant a thorough search.

As far as a historian's judgment can stretch, beside Vallo di Diano and Amatriciano, there are many other corners of non-metropolitan Italy where other such earthquakes could have been prevented from becoming general knowledge by the absence of a Pacca or a Tiberii, and remained undetected in the fringes of Italian «earthquake consciousness». The area affected by the 31 October 2002 Molise earthquake could perhaps be one of these.

Of course, the larger the area affected by its destructive effects, the harder for an earthquake to be completely forgotten. It is unlikely that very large and destructive earthquakes, such as those of 1456 (Southern Italy), 1693 (Sicily) or 1703 (Central Italy) can have been blurred out of recognition, unless perhaps they occurred in the "hic sunt dracones» time-windows of Antiquity and the Early Middle Ages.

It could be, however, much easier for earthquakes whose largest effects affected comparatively small areas, and especially so if such areas should happen to belong to those portions of the Italian territory that were not a subject of foremost interest for any of the large-scale programmes of historical earthquake research launched in the past 30 years and including extensive archive investigation.

\section{Acknowledgements}

This paper was first conceived as a joint venture with Massimiliano Stucchi, who provided crucial insights in its seminal stage and presented its first draft at the 1998 ESC General Assembly (Tel Aviv, Israel). Gratefully ac- knowledging his many generous contributions to this paper, the author claims full responsibility for any mistakes, inconsistencies and unsound ideas marring the final version. Thanks to Gregory Quenet and a nameless reviewer for their suggestions and to Romano Camassi and Emanuela Ercolani for their patience with a MapInfo-challenged one.

\section{REFERENCES}

ACAP (Archivio Capitolino) (1638-1639): Archivio Urbano, Notary Augustinus Theolus, 42, 1639 October 5.

ACVAP (Archivio della Curia Vescovile di Ascoli Piceno) (1652): Sacre Visite, Giulio Gabrielli.

ASFI (Archivio di Stato di Firenze) (1542-1622): Mediceo del Principato, 4148, Avvisi di Napoli e Messina dal 1542 al 1622.

ANTINORI, A.L. (18th century): Annali degli Abruzzi, 22/1, Biblioteca Provinciale 'S. Tommasi' of L'Aquila, Antinoriani MSS (facsimile edition, Bologna 19711973).

BARATTA, M. (1901): I Terremoti d'Italia, Torino (anastatic reprint, Bologna 1979).

Bellabona, S. (1656): Raguagli della città d'Avellino del P[adre] Bacc[elliere] Fra Scipione Bellabona [...] nelli quali si dà notitia d'alcuni antichi luoghi de gl'Irpini. Si descrive la detta città, e sue grandezze, destruttioni, casi successi a coloro, che la dominarono [...], Trani.

Bloch, M. (1997): Apologie pour l'Histoire ou le Métier d'Historien (Nouvelle Edition, Armand Colin/Références, Paris).

Bonito, M. (1691): Terra Tremante, Napoli.

Boschi, E., G. Ferrari, P. Gasperini, E. Guidoboni, G. SMriglio and G. VAlENSISE (Eds.) (1995): Catalogo dei Forti Terremoti in Italia dal 461 A.C. al 1980 (ING, Roma-SGA, Bologna), pp. 974.

Boschi, E., E. Guidoboni, G. Ferrari, G. Valensise and P. GASPERINI (Eds.) (1997): Catalogo dei Forti Terremoti in Italia dal 461 A.C. al 1990 (ING, Roma-SGA, Bologna), pp. 644.

Boschi, E. E Guidoboni, G. Ferrari, D. Mariotti, G. VAlensise and P. Gasperini (Eds.) (2000): Catalogue of Strong Italian Earthquakes from 461 B.C. to 1997, Ann. Geofis., 43 (4), 609-868.

Bracco, V. (1976): Polla. Linee di una Storia, Salerno.

Bragaglia, A.G. (1958): Storia del Teatro Popolare Romano, Roma.

Braudel, F. (1982): La Mediterranée et le Monde Mediterranéen à l'Époque de Philippe II (Librairie Armand Colin, Paris).

BRITISH LIBRARY (1988): Catalogue of Seventeenth Century Italian Books in the British Library, 2, M-Z, London.

Bulgarelli, S. and T. Bulgarelli (1988): Il Giornalismo a Roma nel Seicento, Roma.

CAmassi, R. and M. Stucchi (1997): NT4.1, un Catalogo Parametrico di Terremoti di Area Italiana al di Sopra della Soglia di Danno (NT4.1.1 version), (GNDT, Milano). 
CIurci, F. (17th century): Familiari Ragionamenti delli Commentarii et Annali dell'Aquila, L'Aquila, Biblioteca Provinciale 'S. Tommasi', MS 49.

CPTI Working Group (1999): Catalogo Parametrico dei Terremoti Italiani (ING - GNDT - SGA - SSN, Bologna), pp. 92.

FILANGIERI, R. (1958): I Registri della Cancelleria AngioinaRicostruiti da R.F. con la Collaborazione degli Archivisti Napoletani, 11 (1273-1277), Napoli.

FranchI, S. (1988): Drammaturgia Romana. Repertorio Bibliografico Cronologico dei Testi Drammatici Pubblicati a Roma e nel Lazio, Secc. XVII-XVIII, 1, Roma.

GiUliani, V. (1768): Memorie Storiche Politiche, Ecclesiastiche della Città di Vieste, Napoli.

Guidoboni, E. (Ed.) (1989): I Terremoti Prima del Mille in Italia e nell'Area Mediterranea. Storia, Archeologia, Sismologia (ING, Roma-SGA, Bologna), pp. 765.

Lupachino, N. (1669): Vita di Camillo Orsini [...] descritta dal Sig. Giuseppe Horologi nel 1565, con l'aggiunta in questa terza and ultima impressione, di alcune lettere della Ser. Repubblica di Venetia [...] con elogij di tutti $i$ suoi discendenti, fino al dì d'hoggi, Bracciano.

MAfFeI, G.C. (1564): Scala Naturale, overo Fantasia Dolcissima. Intorno alle Cose Occulte, e Desiderate nella Filosofia, Venezia.

Marcucci, F.A. (1766): Saggio delle Cose Ascolane e de' Vescovi di Ascoli nel Piceno, Teramo.

MARITI, L. (1978): Commedia Ridicolosa: comici di professione, dilettanti, editoria teatrale nel Seicento: storia e testi, Roma.

Massimi, A. (1958): Amatrice e le sue Ville. Notizie storiche, Amatrice.

MattiA, G. (1986): Tolve nella Storia - dall'anno 1000 al 1935, no place.

Memorial TABlet (17th century): Eulogy of Prince Alessandro Maria Orsini's Intervention after the 1639 Earthquake, Amatrice, Palazzo Orsini, in situ.

MerCALli, G. (1891): I terremoti napoletani del secolo XVI ed un manoscritto inedito di Cola Anello Pacca, Boll. Soc. Geol. It., 10 (1891), 179-195.

MINIERI RICCIO, C. (1844): Memorie Storiche degli Scrittori Nati nel Regno di Napoli, Napoli.

Minieri Riccio, C. (1861): Biblioteca Storico-Topografica degli Abruzzi Composta sulla propria Collezione da C.M.R. Direttore della Real Biblioteca Palatina di Napoli, 1, Napoli.

MonaChesi, G. and M. STUCCHI (1997): DOM4.1, un Database di Osservazioni Macrosismiche di Terremoti di Area Italiana al di Sopra della Soglia del Danno, Rapporto Tecnico (GNDT, Milano-Macerata), pp. 1052 (on line http://emidius.mi.ingv.it/DOM/).

Morelli, S. (1993): Una fonte inedita per lo studio della sismologia storica: il «Discorso del Terremoto» di Cola Anello Pacca (1563), Rassegna Storica Salernitana, XI, 247-259.

Mucciarelli, M., G. Valensise, M.R. Gallipoli and R. CAPUTO (2000): Reappraisal of a XVI century earthquake combining historical, geological and instrumental information, in Papers and Memoranda from the First Workshop of the ESC Working Group «Historical Seismology», 1-5 September 1999, Macerata, Italy, edited by V. CASTELLI, 64-67.
Nicolini, F. (1966): Saggio d'un repertorio biobibliografico di scrittori nati o vissuti nell'antico regno di Napoli, Banco di Napoli, Biblioteca del «Bollettino» dell'Archivio Storico, 11, Napoli.

PACCA, C. (16th century): Discorso del Terremoto, ms., Biblioteca della Società Napoletana di Storia Patria di Napoli, Fondo Sismico, 7/A3.

PACCA, C. (1563): Della seconda parte del compendio dell'istoria del Regno di Napoli, il Settimo libro del Dottor Colanello Pacca Napoletano, in Compendio dell'Istorie della Città di Napoli, edited by P. CoLLenuccio, M. Roseo, C. PACCA and T. Costo, Venezia.

PACCA, C. (1591): Della seconda parte del compendio dell'istoria del Regno di Napoli, il Settimo libro del Dottor Colanello Pacca Napoletano, in Compendio dell'Istorie della Città di Napoli, edited by P. CollenUCCIO, M. Roseo, C. PACCA and T. Costo, Venezia.

Ragioni a pro della Serenissima Vittoria Montefeltria della Rovere gran duchessa di Toscana [...] sulla Baronia di Amatrice, sequestrata ad istanza del Regio Fisco per la pretesa devoluzione (1693).

RicCHeTti, D.M. (1983): Castelpagano, Cosenza.

Rossi Da Voltaggio, A.M. (1695): Vita del Venerabile Servo di Dio B[eato] Giuseppe da Leonessa Predicatore Cappuccino della Provincia di S. Francesco, Genova.

Sansone, G. and L. SAnsone (1959): La città di Lioni e Dintorni, Lioni.

SARnelli, P. (1680): Cronologia de' Vescovi et Arcivescovi Sipontini, Manfredonia.

SChiafFino, A. (17th century): Annali Ecclesiastici della Liguria, Genoa, Biblioteca Civica Berio, MS M.R. 3.1.5.

SCOGLIO, * (17th century): Annali Ecclesiastici (in Bonito, 1691).

SERIPANDO, G. (16th century): Giornale dal 1513 al 1562, Naples, Biblioteca Nazionale "Vittorio Emanuele III", MS IX.C. 42

Soria, F. (1781): Memorie Storico Critiche degli Scrittori Napoletani, Napoli.

TAFURI, G.B. (1752): Istoria degli Scrittori Nati nel Regno di Napoli, 3/2, Napoli.

TIBERII, C. (1639a): Nuova, e vera relatione del terribile, e spaventoso terremoto successo nella città della Matrice, e suo stato, con patimento ancora di Accumolo, e luoghi circonvicini, sotto li 7 del presente mese di ottobre 1639, con la morte compassionevole di molte persone, la perdita di bestiami d'ogni sorte, e con tutto il danno seguito fino al corrente giorno. Con ogni diligenza, e certezza descritta da Carlo Tiberii Romano, per memoria d'un caso così miserando, e lagrimevole, Roma.

TIBERII, C. (1639b): Nuova e vera relatione del terribile, e spaventoso terremoto sucesso nella città della Matrice e suo stato, con patimento ancora di Accumulo, e luoghi circonvicini, sotto li 7 del mese di ottobre 1639. Con la morte compassionevole di molte persone, la perdita de bestiami d'ogni sorte, e con tutto il danno seguito fino al corrente giorno. Con ogni diligenza, $e$ certezza descritta da Carlo Tiberij, romano, per memoria d'un caso così miserando, e lagrimevole. Aggiuntovi di più altri successi dalli 17 del sodetto mese 
fin all'hora presente; dove s'intende le gran ruvine di Monte Reale, Poggio, Cancello e ancora con spavento nuovamente di Recanati, e Rieti nel detto tempo, Roma e Milano.

TiBerII, C. (1641): Hoggi corre quest'usanza. Comedia del Signor Carlo Tiberii Romano, Il Disprezzato Accademico Nascosto, Ronciglione.

ToppI, N. (1678): Biblioteca Napolitana [...], Napoli.

Ugurgieri Azzolini, I. (1649): Le Pompe Sanesi, Pistoia.
Villani, M. (14th century): Cronica, edited by G. PORTA, Parma, 2 voll.

VIPERA, M. (1635): Chronologia Episcoporum, et Archiepiscoporum Metropolitanae Ecclesiae Beneventanae, Napoli.

(received February 13, 2003 accepted August 4, 2003) 
